CLINICAL HEMORHEOLOGY, Vol. 12, p. 972, 1992

$0271-5198 / 92 \$ 5.00+.00$ Printed in the USA.

Copyright $\odot 1992$ Pergamon Press Ltd. All rights reserved.

\title{
CONTENTS OF BIORHEOLOGY, VOLUME 29, NUMBER 2/3
}

T.C. Fisher, R.B. Wenby and

H.J. Meiselman

G.H. Müller, H. Schmid-Schönbein and H.J. Meiselman

N. Uyesaka, S. Hasegawa, N. Ishioka, R. Ishioka, H. Shio and A.N. Schechter

J. Mellema, H.J. Holterman,

H.A. Waterman, C. Blom

and E.J. 's-Gravenmade

S. Yamaguchi, T. Yamakawa and H. Niimi

J. Mayer, Z. Pospísil and J. Litzman

F. Lacour, M.M. de Ficquelmont-Loizos and A. Caprani

P.C. Braga, L. Allegra, G. Dall'Oglio, M. Angelini and A. Mocchi

K.R. Hallows and R.S. Frank

M. Nakamura and N. Satake

K. Murakawa, M. Kohno, Y. Kinoshita and

T. Takeda

D. Lee and J.J. Chiu

S.-K. Wang and N.H.C. Hwang
Contents

Papers

185 Pulse shape analysis of RBC micropore flow via new software for the cell transit analyser (CTA)

203 Development of viscoelasticity in heated hemoglobin solutions

217 Effects of superoxide anions on red cell deformability and membrane proteins

231 Rheological aspects of mucin-containing solutions and saliva substitutes

251 Cell-free plasma layer in cerebral microvessels

261 The mechanism of erythrocyte sedimentation in Westergren's examination

273 Adsorption of bovine serum albumin onto glassy carbon in a couette flow. Effect of shear rate on the adsorption kinetics and on the structure of the adsorbed proteic layer

285 A new rheometer with special features designed for bronchial mucus analysis in clinical practice

295 Changes in mechanical properties with DMSO-induced differentiation of HL-60 cells

311 Unsteady flow of Casson fluids through the eccentric circular tube

323 Application of diffractometry and a linear image sensor to measurement of erythrocyte deformability

337 A numerical simulation of intimal thickening under shear in arteries

Review Article

353 On transport of suspended particulates in tube flow

379 Errata

381 Contents of CLINICAL HEMORHEOLOGY

Volume 11 , Numbers $3 / 4$ 